\title{
Fatty acid profiles in different fish species in Lake Baikal
}

\author{
O. Grahl-Nielsen ${ }^{1, *}$, E. Averina ${ }^{2}$, N. Pronin ${ }^{3}$, L. Radnaeva ${ }^{2,4}$, R. Käkelä5 \\ ${ }^{1}$ Department of Chemistry, University of Bergen, 5007 Bergen, Norway \\ ${ }^{2}$ Baikal Institute of Natural Management SB RAS, 630033 Ulan-Ude, Russia \\ ${ }^{3}$ Institute of General and Experimental Biology SB RAS, 630033 Ulan-Ude, Russia \\ ${ }^{4}$ Buryat State University, 630000 Ulan-Ude, Russia \\ ${ }^{5}$ Department of Biosciences, University of Helsinki, PO Box 65, 00014 Helsinki, Finland
}

\begin{abstract}
The fatty acid (FA) composition in the heart tissue and white muscle of 13 species/ecoforms of Lake Baikal fish was determined. All the FAs usually found in freshwater or marine fish were detected in both tissues of all species studied. White muscle contained lower levels of saturated and monounsaturated FAs (SAFAs and MUFAs), and higher levels of polyunsaturated FAs (PUFAs) than heart tissue. The n3/n6 PUFA ratio ranged between 1.3 and 3.2 in heart tissue and 1.4 and 6.6 in white muscle, typical for freshwater fish. The most prominent n3 PUFAs, 20:5n3 and 22:6n3, occurred at levels comparable to those found in corresponding species in other freshwater lakes and rivers and also in marine fish. The FA compositions were species specific, following the taxonomic distinction between the species. Apparently, dietary FAs are modified significantly through the metabolism of the fish to produce the species-specific FA composition necessary for the structural lipids of heart tissue and white muscle.
\end{abstract}

KEY WORDS: Heart - White muscle $\cdot$ Thirteen species/ ecoforms · Fatty acid composition · Taxonomy

Resale or republication not permitted without written consent of the publisher

\section{INTRODUCTION}

Lake Baikal, eastern Siberia, is the world's oldest (25 million yr), deepest (1637 m) and largest (23000 km³) freshwater reservoir. The Baikalian fauna diverged in the Tertiary period, and in 2001 counted 2595 species, 1455 of them being endemic (Timoshkin 2001). Despite its enormous volume, the ecosystem of the lake is vulnerable to climate change (Mackay et al. 2006, Hamp-

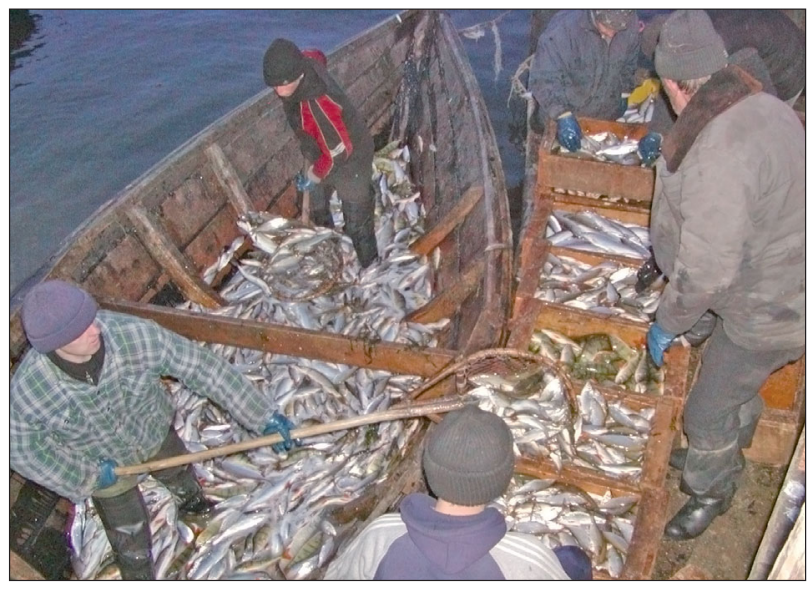

Sorting the night's catch at a fishing village by Lake Baikal. Image: Otto Grahl-Nielsen

ton et al. 2008, Moore et al. 2009). There is a growing interest in monitoring the anticipated changes in aquatic food webs using FA profiles or other biochemical markers in consumer tissues (e.g. Cooper et al. 2009, Sun et al. 2009). Unfortunately, data on the lipids and FAs of Lake Baikal fauna are still insufficient and fragmentary, and studies involving the analysis of several species at each trophic level are needed.

The Baikalian fauna is considered to be unique, in that the composition of tissue lipids is characterized by high levels of long-chain polyunsaturated FAs (PUFAs), a feature typical of marine species (Morris 1984). Morris (1984) determined the FAs in some of the most abundant copepods, gammarides and turbellarians, and in 2 species of endemic fish, big and small 
golomyanka, Comephorus baikalensis and C. dybow$s k i$, respectively. The tissue FAs of these 2 Comephorus species were also determined in other studies (Ju et al. 1997, Kozlova \& Khotimchenko 2000). In addition, FA data are available for 2 Cottocomephorus (Kozlova $\&$ Khotimchenko 1993) and 1 Coregonus (omul) species of fish (Ju et al. 1997), as well as for a series of sponges, molluscs and amphipods (Dembitsky et al. 1994, and references therein). In the patchy fish FA data published, there are large variations among species, among different tissues and also among different reproductive stages. This variability calls for additional investigations on the FA composition of Lake Baikal fish.

In the present study, the tissue FA compositions of 13 species/ecoforms of Lake Baikal fish were determined. As most of these species are used for human consumption, it was reasonable to select the white muscle of the filet as a target for investigation. We also investigated the heart tissue. Heart tissue lipids are mostly polar, and their FA compositions are well suited for the identification of fish species and stocks (Grahl-Nielsen 2005). Our aim was to study the magnitude of interspecific variation in FA composition. Another important question was whether the FA compositions of the fish reflected the taxonomic relationships between the species. The present study provides an assessment of the factors determining tissue FA composition.

\section{MATERIALS AND METHODS}

Sampling and analysis. Fish from 13 species/ecoforms (Table 1) were collected by gill net in Chivyrkuyskiy Bay on the eastern shore of Lake Baikal at $53^{\circ} 40^{\prime} \mathrm{N}$, $109^{\circ} 00^{\prime} \mathrm{E}$ in late October 2004. The 2 golomyanka species were collected at 120 to $150 \mathrm{~m}$ depth, and the other species at approx. 3 to $4 \mathrm{~m}$. The water temperature in the bay at the time of collection was ca. 2 to $3^{\circ} \mathrm{C}$, measured at both 3 and $12 \mathrm{~m}$ depth, about the same as the year-round constant temperature of 3.1 to $3.5^{\circ} \mathrm{C}$ in the open lake (Galasii 1993). Between 0 and $10 \mathrm{~m}$, the temperature may rise to $10^{\circ} \mathrm{C}$ during the summer. All specimens were sexually mature, between 4 and $7 \mathrm{yr}$ old, determined by microscopy of the scales and according to Chugunova (1959), with both sexes equally represented. Fish were immediately brought fresh to the nearby laboratory at the Chivyrkuysky Biological Station, Institute for General and Experimental Biology (SB RAS). Tissue samples, weighing approximately 30 to $50 \mathrm{mg}$, were immediately processed. The heart was carefully washed with distilled water to remove blood and dried on filter paper, and a sample was cut from the tip. From the white dorsal muscle, a sample was cut from the side about $2 / 5$ of the distance from the snout to the tail, carefully avoiding red muscle, skin and bone.
Table 1. Taxonomy of the fish species/ecoforms investigated (according to Matveev et al. 2008). *Endemic species. Coregonous migratorius is divided into 3 ecoforms

\begin{tabular}{|c|c|}
\hline Category & Taxon \\
\hline Superorder & Protacanthopterygii \\
\hline Order & Salmoniformes \\
\hline Family & Salmonidae \\
\hline Subfamily & Coregoninae \\
\hline Genus & Coregonus \\
\hline Species & C. migratorius* \\
\hline \multirow[t]{3}{*}{ Common name (abbr.) } & Littoral omul (O) \\
\hline & Pelagic omul (M) \\
\hline & Deepwater omul (U) \\
\hline Species & C. baikalensis* \\
\hline Common name (abbr.) & Whitefish (W) \\
\hline Subfamily & Thymallinae \\
\hline Genus & Thymallus \\
\hline Species & T. baikalensis* \\
\hline Common name (abbr.) & Grayling (G) \\
\hline Order & Esociformes \\
\hline Family & Esocidae \\
\hline Genus & Esox \\
\hline Species & E. lucius \\
\hline Common name (abbr.) & Pike (P) \\
\hline Superorder & Ostariophysii \\
\hline Order & Cypriniformes \\
\hline Family & Cyprinidae \\
\hline Subfamily & Leuciscinae \\
\hline Genus & Leuciscus \\
\hline Species & L. leuciscus \\
\hline Common name (abbr.) & Dace (D) \\
\hline Species & L. idus \\
\hline Common name (abbr.) & Ide (I) \\
\hline Genus & Rutilus \\
\hline Species & R. rutilus \\
\hline Common name (abbr.) & Roach (R) \\
\hline Subfamily & Cyprininae \\
\hline Genus & Carassius \\
\hline Species & C. auratus \\
\hline Common name (abbr.) & Silver carp $(C)$ \\
\hline Superorder & Acanthopterygii \\
\hline Order & Perciformes \\
\hline Family & Percidae \\
\hline Genus & Perca \\
\hline Species & P. fluviatilis \\
\hline Common name (abbr.) & Perch (E) \\
\hline Order & Scorpaeniformes \\
\hline Family & Cottidae \\
\hline Subfamily & Cottocomephorinae \\
\hline Genus & Comephorus \\
\hline Species & C. baikalensis* \\
\hline Common name (abbr.) & Big golomyanka (B) \\
\hline Species & C. dybowski* \\
\hline Common name (abbr.) & Small golomyanka (S) \\
\hline
\end{tabular}

In some cases only one of the tissues was sampled from a specimen, and, for the golomyankas, subsamples from the hearts were not collected, due to the small size of the hearts. For pelagic omul Coregonus migratorius only 2 and for silver carp Carassius auratus only 3 specimens were netted. For the other species, between 8 and 22 specimens were netted. The samples 
were transferred to $15 \mathrm{ml}$ thick-walled glass tubes, and $1 \mathrm{ml}$ of anhydrous methanol containing $2 \mathrm{M} \mathrm{HCl}$ was added. The atmosphere in the tubes was exchanged with nitrogen gas, the tubes were securely closed with Teflon-lined screw caps and placed in an oven for $2 \mathrm{~h}$ at $90^{\circ} \mathrm{C}$ for complete methanolysis (Meier et al. 2006). After cooling to room temperature, the tubes were opened and the methanol was evaporated down to ca. $0.5 \mathrm{ml}$ by a stream of nitrogen gas and $0.5 \mathrm{ml}$ distilled water was added to reduce the solubility of the FA methyl esters (FAME) formed, which were extracted with $2 \times 1 \mathrm{ml}$ hexane.

One microliter of the combined hexane extracts were injected splitless (the split was opened after $4 \mathrm{~min}$ ) and were chromatographed on a $25 \times 0.25 \mathrm{~mm}$ (i.d.) fused silica column with polyethylene-glycol (PEG) for the stationary phase, with a thickness of $0.2 \mu \mathrm{m}$ (CP-WAX 52CB Chrompack), and helium at 20 psi as the mobile phase. The column was mounted in a Hewlett-Packard 5890A gas chromatograph equipped with a HewlettPackard 7673A autosampler and a flame-ionisation detector (FID). The injector temperature was set at $260^{\circ} \mathrm{C}$, and the detector temperature at $330^{\circ} \mathrm{C}$. The oven was programmed as follows: $90^{\circ} \mathrm{C}$ for $4 \mathrm{~min}, 30^{\circ} \mathrm{C}$ $\min ^{-1}$ up to $165^{\circ} \mathrm{C}$, then $3^{\circ} \mathrm{C} \min ^{-1}$ up to $225^{\circ} \mathrm{C}$, where it was left isothermal for $10.5 \mathrm{~min}$ before cooling for the next run. The FID signal was A/D converted, recorded, stored and treated in Chromeleon 6.60 software.

The chromatographic peaks were identified by comparison with a chromatogram of a standard mixture of 20 FAMEs, GLC reference standard 68D from Nu-ChekPrep (Elysian), by chromatographing selected samples under identical conditions with mass-spectrometric detection on a Fison 800 GC-MS, and by using our experience from previous gas chromatograph (GC) analyses of FAMEs under identical conditions. To monitor the performance of the column in the GC, the standard mixture of FAMEs was chromatographed at regular intervals for each tenth sample. Empirical response factors relative to $18: 0$ were computed for the 20 FAMEs present in known amounts in the standard mixture. The response factors for each of the FAMEs not present in the standard mixture were estimated by comparison with the standard FAMEs which resembled them most closely in terms of chain length and number of double bonds. The areas of the FAME peaks were corrected with the response factors, and the relative amount of each FA in a sample was expressed as a percent of the sum of all FAs in the sample.

Data analysis. Corrected areas of chromatographic peaks were subjected to multivariate statistics using principal component analysis (PCA) available in the SIRIUS 7.0 software package (Kvalheim \& Karstang 1987). For this purpose, only those 30 FAs present with levels $>0.1 \%$ in all samples were used. The variables present in lower levels contributed more noise than real information to the data. The relative values (i.e. percent of the sum) of the FAs were logarithmically transformed, thereby levelling out the quantitative differences among FAs. With each sample positioned in the multi-dimensional space described by the logtransformed variables (FA), new coordinates (principal components, PCs) in the directions of the largest and second largest variance among the samples were computed. In this manner, the relationship between the samples could be described in much fewer dimensions than the original, retaining the systematic variation among the samples. The relative positions of the samples were displayed by projecting them on a plane defined by 2 new coordinates (i.e. PC1 and PC2), resulting in $\mathrm{PC}$-plots.

The PC-plots are only qualitative displays of the relationship among the samples, and do not cover the total variation among them, nor do they quantify the differences among the samples. Quantitative measures of the differences among the samples were determined by Soft Independent Modeling of Class Analogy (SIMCA) (Wold \& Sjöström 1977) available in the software package SIRIUS (Kvalheim \& Karstang 1987). This computation was based on the 22 most abundant FAs. The normalized values were standardized within each species (i.e. by dividing the values for each FA by the standard deviation of that FA within each species). PCs were then fitted to the samples of each species, determining the number of significant components, adequately describing the species, by cross validation (Wold 1978). Space-filling models were then constructed around the PC(s) with an outer 95\% confidence limit, $\mathrm{RSD}_{\max }$ (relative standard deviation). Finally, the distance to the model, RSD, was determined for each fish sample. In SIMCA, a given fish belongs to a species when its RSD is lower than the outer limit, $\mathrm{RSD}_{\max }$ of the model.

\section{RESULTS}

In total, 37 FAs were determined in the heart tissue of 11 species/ecoforms and in the white muscle of 13 species/ecoforms of Lake Baikal fish (see Tables S1 \& $\mathrm{S} 2$ in the supplement at www.int-res.com/articles/ suppl/b013p001_supp.pdf). The large standard deviations indicated large variations among the individual fish within each species. The relative amounts of FAs varied from $<0.1 \%$ to a maximum of $40.9 \%$. The most prominent saturated FAs (SAFAs) in the tissues were 16:0 (13 to $23 \%$ ) and 18:0 (4 to $12 \%$ ). The monounsaturated FAs (MUFAs) with the highest percentages were $18: 1 \mathrm{n} 9$ (5 to $13 \%$ ) and $16: 1 \mathrm{n} 7$ (2 to $8 \%$ ). The PUFAs in highest proportions were 20:5n3 (EPA), rang- 
ing from 3 to $7 \%$ and from 4 to $15 \%$ in the heart and muscle tissue, respectively, 22:6n3 (DHA) (8 to 22\% and 9 to $40 \%$ ) and $20: 4 \mathrm{n} 6$ (5 to $12 \%$ and 4 to $10 \%$ ) (Tables S1 \& S2).

The white muscle contained lower levels of SAFAs, clearly less MUFAs and, consequently, more PUFAs than the heart tissue. In general, the n3/n6 PUFA ratio was higher in white muscle than in the heart (Tables S1 \& S2). The 2 Cyprinidae species, ide and carp, however, had similarly low ratios in both tissues.

There were also species-specific differences in the FA composition of the heart tissue and white muscle. The PCA of the samples of heart tissue showed that the fish fell into 3 clearly distinguished clusters, with the omuls grouped closely together on the left side and the species from the Cyprinidae family on the right side of the PCplot (Fig. 1). Whitefish, grayling, pike and perch fell between these 2 groups. In terms of the white muscle samples, the same 3 groups of species were not as well separated as for the heart tissue (Fig. 2). In the case of white muscle, the largest distinction was found between the golomyankas on the right side of the plot and all the others on the left side of the PC-plot. The FAs most important for the distinction of the golomyankas from the other species are shown by their loadings in the PC-plot. The FAs on the right side of the plot had higher relative values in the golomyankas, the FAs on the left side of the plot had lower relative values. This corresponded with the values given in Table S2.

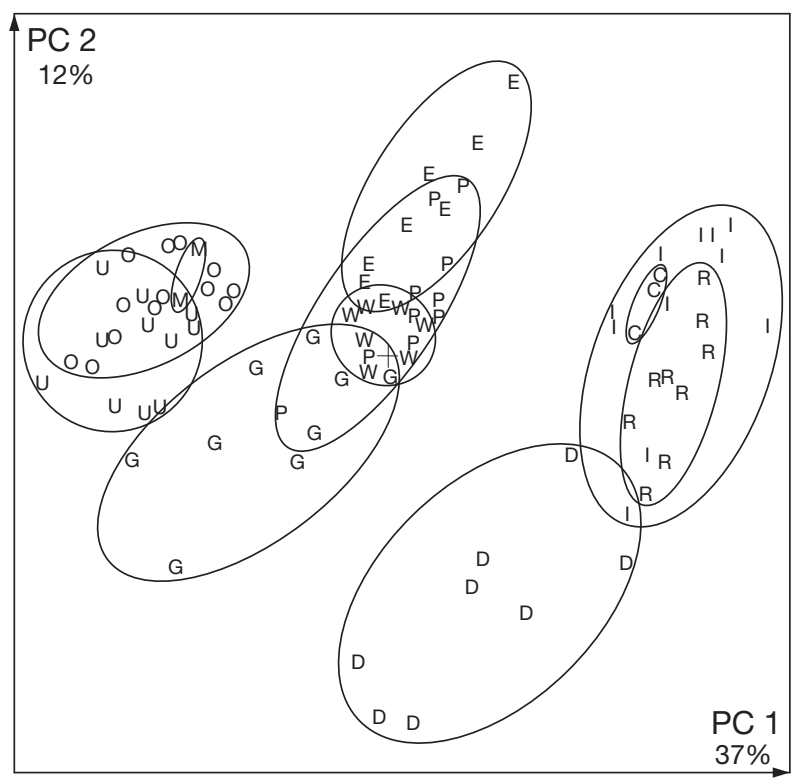

Fig. 1. Principal component (PC)-plot based on 30 fatty acids in the heart tissue of 93 fish from 11 species/ecoforms (see Table 1 for abbreviations). Each symbol represents 1 fish, and fish of a common species are encircled. The percentage variation along each PC is shown. The origin of the plot is marked with a cross

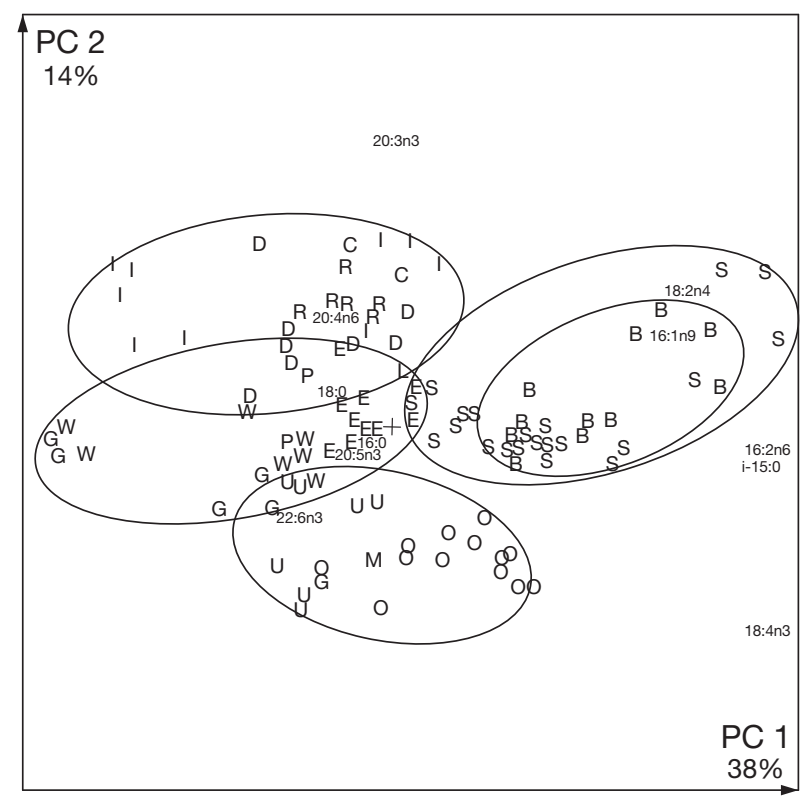

Fig. 2. Principal component (PC)-plot based on 30 fatty acids (FAs) in the muscle tissue of 100 fish from 13 species/ecoforms (see Table 1 for abbreviations). Each symbol represents 1 fish. The 3 omul ecoforms $\mathrm{O}, \mathrm{U}$ and $\mathrm{M}$ are encircled; likewise the 4 Cyprinidae species D, I, R and C; the 2 Salmonidae W and G; and the Esocidae P plus the Percoidae E. The big (B) and small golomyankas (S) are encircled separately. The FAs of the greatest importance for the discrimination between stocks are displayed in the same coordinate system. The species on the right side of the plot contain higher relative proportions of the FAs located on the same side of the plot. The same applies for the samples on the left side and upper and lower sides of the plot. The percentage variation along each PC is shown. The origin of the plot is marked with a cross

However, the large individual differences among the fish within each species resulted in large overlaps of the species in the PC-plots (Figs. $1 \& 2$ ). The projections of the samples in the PC1-PC2 plane covered only about $50 \%$ of the total variation among the samples. To obtain a better comparison of the differences among the species for the 2 tissues, PCA was carried out by using the average values presented in Tables S1 \& S2. This time the muscle samples of the golomyankas were not included in the computation, since they were clearly distinct from all the others (Table S2, Fig. 2) and would have dominated the analysis with too large an effect on the positions of the other species in the plot (since PCs were computed relative to all samples in the matrix). After removing the golomyanka samples from the analysis, the relationships of the other species revealed essentially the same groupings for the heart and white muscle (Fig. 3). The 3 omul ecoforms were grouped closely together on the left side of the plots, in the close vicinity of whitefish. Indeed, the omuls and whitefish belong to the same genus (Coregonus, superorder Pro- 
tacanthopterygi; (Table 1). The 4 Cyprinidae species silver carp, dace, ide and roach, which represent a different superorder (Ostariophysii) - appeared on the right side of the plots.

The 3 remaining species-grayling (belonging to the same Salmonidae family as omul and whitefish), pike (an Esocidae species distantly related to Salmonidae, but still from the same superorder of Protacanthopterygii) and perch (superorder Ostariophysii) — all grouped together in the middle of the plots, between the omuls and the Cyprinidae (Fig. 3).

The loadings of the FAs mainly responsible for the distinction among the species are shown in the PCplots in Fig. 3. The same FAs distinguished among the species in both tissues. The FAs 18:4n3, 16:2n6 and 14:0, on the left side of the plots, had higher relative values in omuls and whitefish than in the other species, and the same 9 FAs, with 2 exceptions, were found on the right side of the plots (i.e. with lower relative values in omuls and whitefish than in the other species).

The PC-plots (Figs. 1 to 3 ) indicate differences between the species/ecoforms. However, due to the large individual variation in FA profiles within each species, indicated by the large standard deviations (Tables S1 \& S2), it was pertinent to test if the tissue FA pattern of each fish was typical for the species/ecoforms and different from the FA patterns of the other species. Therefore, separate space-filling models were created for each species by SIMCA (Wold \& Sjöström 1977). By computing the distances to every model (as residual standard deviations) for every fish, we found that the distinction among species was as good as complete for the heart tissue (Table 2). Of the total number of 93 samples, 80 were correctly classified, only 1 was classified as the wrong species, 12 fish were not classified (i.e. did not fit into any model), and 9 fish were classified in another species in addition to their own. For example, of the 14 littoral omul, 12 were correctly classified, but 4 of these were also classified as deepwater omul; 2 littoral omul were non-classified. The only incorrectly classified fish was a roach classified as an ide.

For white muscle, the discrimination was as good as for heart tissue: among 108 fish, 94 were correctly classified, none were incorrectly classified, 14 were nonclassified and 11 were classified into 2 different species (Table 3).

\section{DISCUSSION}

The heart tissue and white muscles of 13 species/ ecoforms of Baikal fish contained high proportions of long-chained n3 PUFAs. This is a characteristic usually attributed to marine fish. However, since the tissue
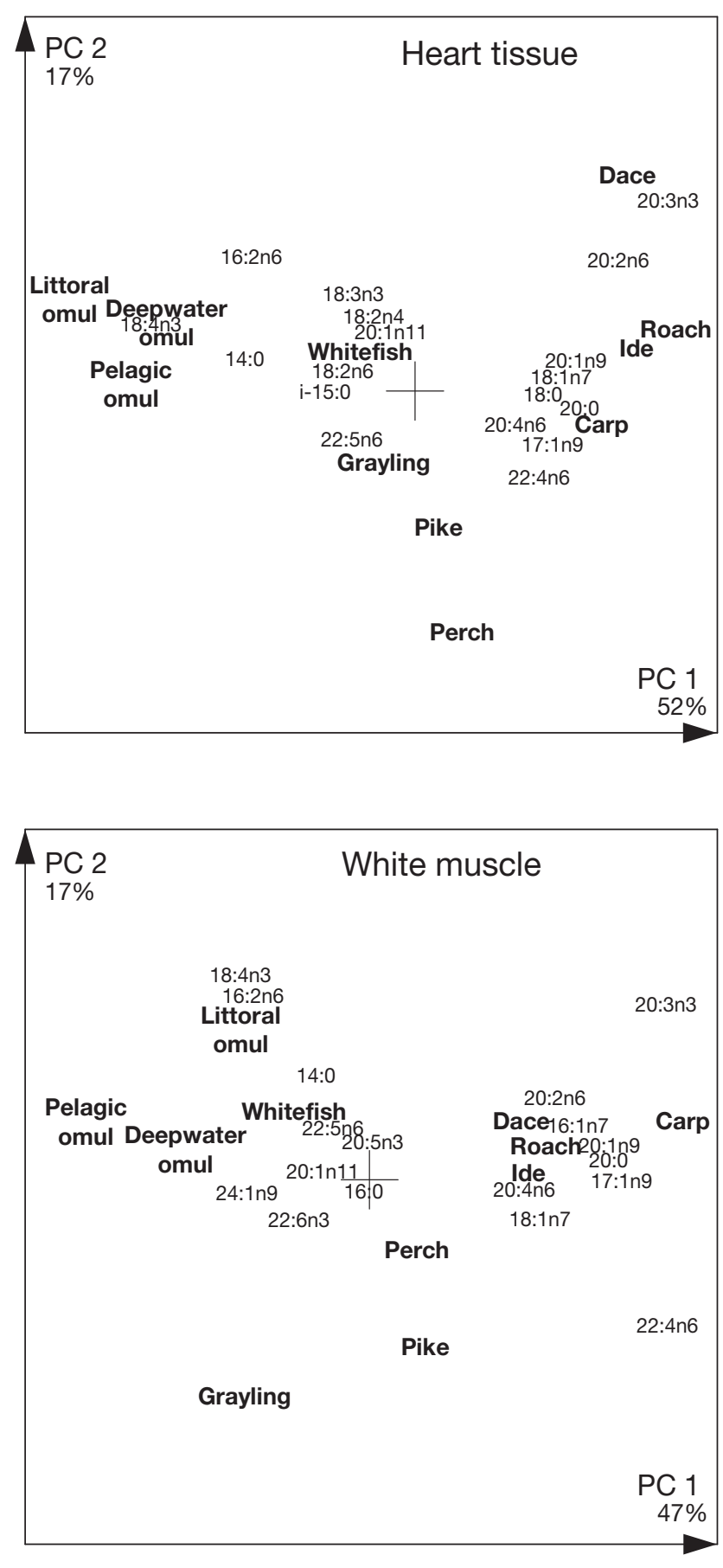

Fig. 3. Principal component (PC)-plots based on the average values of 30 fatty acids (FAs) in heart tissue and white muscle of the various fish species/ecoforms from Tables S1 \& S2 in the supplement at www.int-res.com/articels/suppl/b013p001_ supp.pdf. The FAs of the greatest importance for the discrimination between stocks are displayed in the same coordinate system. The species on the right side of the plots contain higher relative proportions of the FAs located on the same side of the plot. The same applies for the species on the left side and upper and lower sides of the plots. The percentage variation along each PC is shown. The origins of the plots are marked with crosses. For taxonomic names, see Table 1 


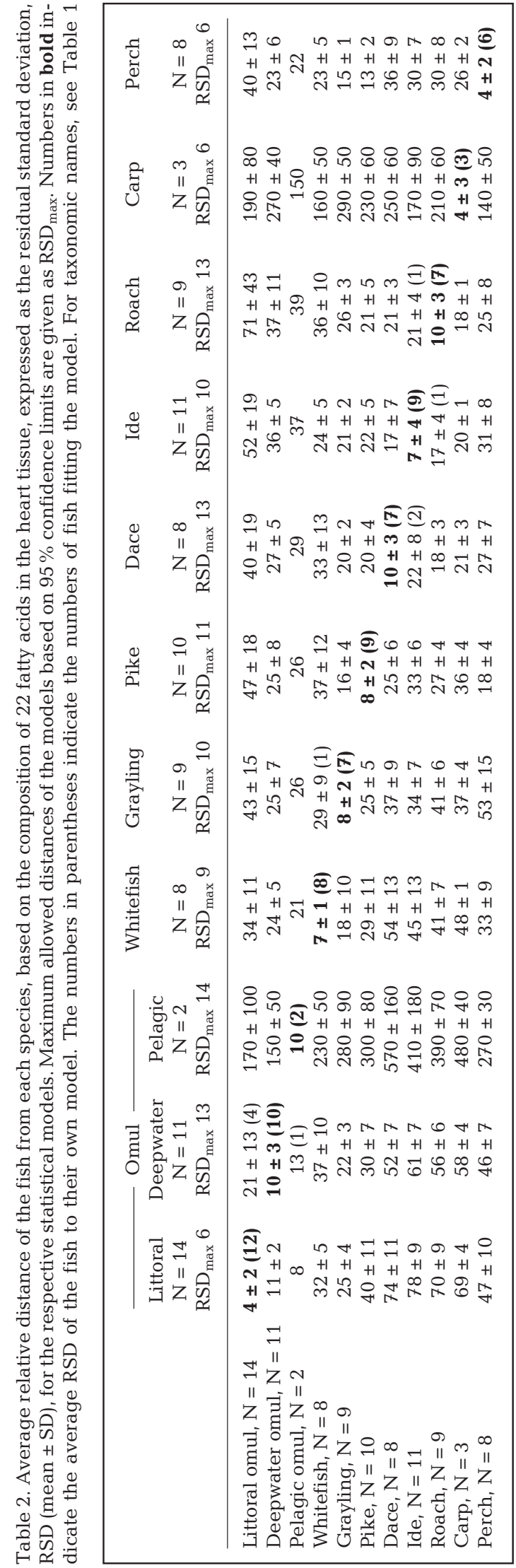

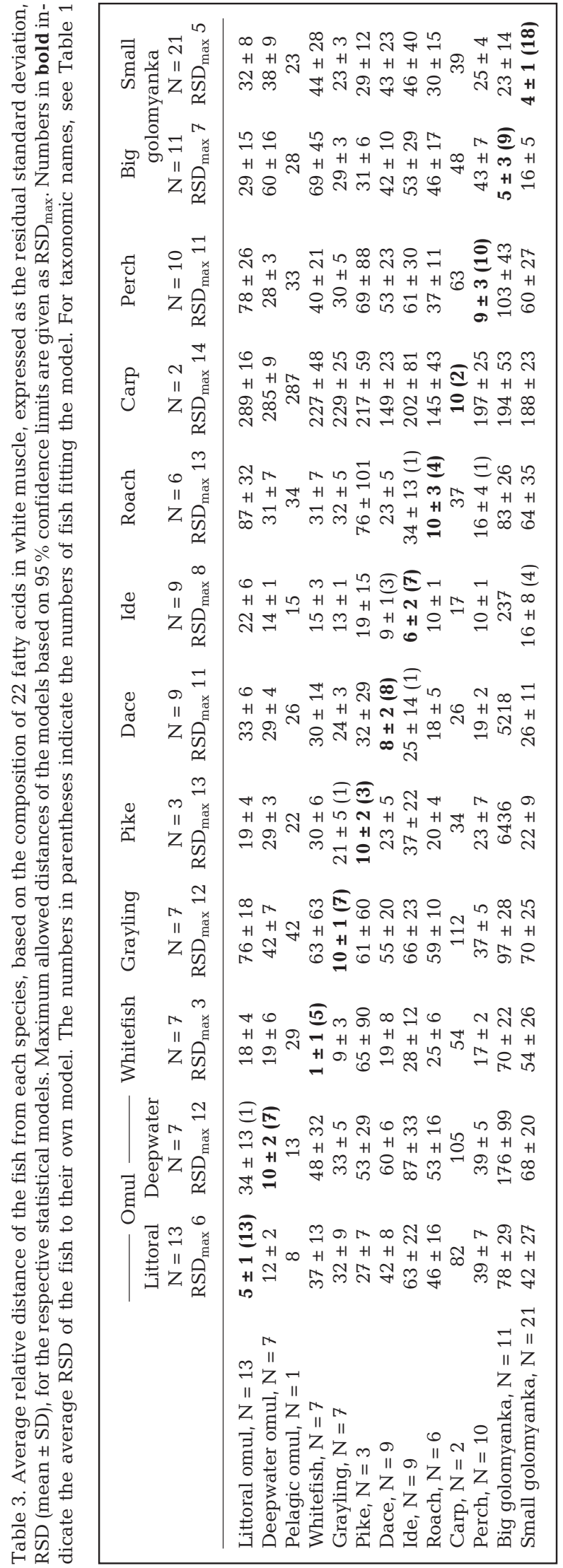


levels of the n6 PUFAs were also high ( 7 to $23 \%$ ), the n3/n6 PUFA ratios were relatively low (1.3 to 6.6). This ratio typically ranges from 1 to 3 in freshwater fish and 8 to 18 in marine fish (Henderson \& Tocher 1987). Thus, this key feature places most of the examined Baikal species in the freshwater group, and some species between the freshwater and marine groups (Tables S1 \& S2). Our results are in good agreement with those of Kozlova \& Khotimchenko (1993, 2000), who found similar low ratios for the small and big golomyankas, and for 2 other Baikal species (not analysed in the present study) Cottocomephorus grewingki and C. inermis.

Comparison of the proportions of EPA and DHA in omul and small and big golomyankas with other studies is somewhat difficult because of differences in the analytical methods. Ju et al. (1997) analysed homogenized whole fish (not distinguishing between the 3 ecoforms), and they did not determine EPA. Nevertheless, the proportions of DHA corresponded with our findings: highest in the omul, with values ranging from 20 to $30 \%$; lower in small golomyanka (10 to $17 \%)$; and lowest in big golomyanka ( 0.3 to $14 \%$ ). Our values ranged from 30 to $37 \%$ for the 3 omul ecoforms, and were $19 \%$ for small golomyanka and $9 \%$ for big golomyanka. Kozlova \& Khotimchenko (2000) examined the polar and neutral lipids in the muscles of the 2 golomyanka species. The proportions of EPA and DHA they found in polar lipids, which can best be compared to proportions found in total lipids, were 11 and $21 \%$, respectively, in small golomyanka and 8 and $13 \%$ in big golomyanka. These values are close to our values of 10 and $20 \%$ EPA and DHA, respectively, in small golomyanka and 4 and $9 \%$ in big golomyanka.

The high percentages of PUFAs in Baikal fish have been explained by low water temperature in the lake, resulting in a high degree of unsaturation of the membrane FAs (Morris 1984). Certainly abiotic factors, especially water temperature, set criteria for the overall acyl chain melting points and lipid fluidity in different tissues of ectothermal fish (Käkelä et al. 2008, Velansky \& Kostetsky 2009). However, a given overall fluidity level can be met by various FA compositions, and often the fluidity of cellular membranes can be adjusted by converting SAFAs to MUFAs, while the PUFA levels remain unaltered (Brooks et al. 2002). Thus, phylogenetic differences providing the species with certain physiological properties may be important determinants of the tissue FA composition.

Considering the very large variation in FA composition among the 13 fish species/ecoforms, with up to 4-fold difference for DHA in the white muscles (Table 2), it is difficult to provide a common explanation for the tissue FA profiles of Lake Baikal fish. Also, the proportions of long-chain PUFAs in the Baikal fish were by no means exceptionally high compared to freshwater fish from other rivers/lakes with different temperature variations (Table 4). Comparisons could only be made for white muscle FAs, since there have been no other investigations of the FAs in heart tissue for the species studied here. Thus, the low temperature of the Baikal water appears to be a minor factor in determining the generally high percentages of PUFAs.

We distinguished the 13 fish species/ecoforms by way of the FA profiles in heart tissue and white muscle (Tables $2 \& 3$ ) and found that the distinctions parallelled the taxonomic differences (Table 1, Figs. 1 to 3). The 3 omul ecoforms (pelagic, deepwater and littoral omul) have previously been distinguished from one another using morphology (Bronte et al. 1999) and mitochondrial DNA (Burnham-Curtis et al. 1999). In the present study, we used FA composition to differentiate between the 3 omul ecoforms (Tables $2 \& 3$ ), although the number of pelagic omul was too small $(n=2)$ for solid conclusions. The present study shows that the tissue FA profile can be used as a robust identifier, even at the ecoform level. This identification method has been successfully used on herring stocks (Grahl-Nielsen \& Ulvund 1990), mackerel stocks (Grahl-Nielsen 2005), striped bass stocks (Grahl-Nielsen \& Mjaavatten 1992), populations of cod (Joensen et al. 2000), stocks of redfish (Joensen \& Grahl-Nielsen 2004) and different strains of salmon (Grahl-Nielsen \& Glover 2010).

There are several possible explanations for the large variation in FA profiles between different species in Lake Baikal (Tables S1 \& S2) and within the same species in other rivers/lakes of the world (Table 4). A major question is: How important is foraging ecology in determination of the FA composition of tissues? In general, there is a strong tendency for certain types of FAs to be incorporated into the sn- 1 and sn- 2 positions of the glycerol backbone of the structural phospholipids of muscles, and this restricts the ability of the acyl chains to reflect diet (Hishikawa et al. 2008). However, many studies have indicated that the FA compositions of the muscles of freshwater fishes are less influenced by diet than those of marine fishes, because of their natural ability to elongate and desaturate 18:2n6 (linoleic acid) and 18:3n3 ( $\alpha$-linolenic acid) into their longer, biologically active homologues (Bell et al. 1986, Henderson \& Tocher 1987, Olsen et al. 1990, Xu \& Kestemont 2002, Xu et al. 2002).

The FA composition of the heart tissue was different from that of the white muscle tissue (Tables S1 \& S2). Nevertheless, the groupings of the species on the PCplots were similar for the heart and muscle samples (Figs. 1 to 3). Thus, the ingested FAs have been modified differently during deposition in the 2 tissues, but the differences between the species were the same, caused by the same FAs, as judged from the loadings 
Table 4. Relative amounts, as percentage of total fatty acids (FAs), of the most prominent polyunsaturated fatty acids (PUFAs) and the n3/n6 PUFA ratio in white muscles in Baikal fish and the same species from other parts of the world. M/F: male/female. For taxonomic names, see Table 1

\begin{tabular}{|c|c|c|c|c|c|}
\hline & $20: 5 n 3$ & $22: 6 n 3$ & $20: 4 n 6$ & $\mathrm{n} 3 / \mathrm{n} 6$ & Source \\
\hline \multicolumn{6}{|l|}{ Perch } \\
\hline Baikal & 7 & 27 & 9 & 2.8 & Present paper \\
\hline Swedish lake $^{a}$ & 9 & 29 & 10 & 2.7 & Ahlgren et al. (1994) \\
\hline Meuse River & 9 & 25 & 6 & 3.6 & Blanchard et al. (2005) \\
\hline Rhine River & 13 & 37 & 7 & 5.9 & Mairesse et al. (2006) \\
\hline Lake Geneva & 13 & 32 & 10 & 3.8 & Mairesse et al. (2006) \\
\hline North Polish lake & 7 & 17 & 7 & 1.6 & Jankowska et al. (2010) \\
\hline Italian lake & 6 & 18 & 8 & 2.5 & Orban et al. (2007) \\
\hline \multicolumn{6}{|l|}{ Pike } \\
\hline Baikal & 7 & 31 & 7 & 3.1 & Present paper \\
\hline Swedish lake $\mathrm{a}^{\mathrm{a}}$ & 9 & 31 & 11 & 2.7 & Ahlgren et al. (1994) \\
\hline Polish lake $1^{\mathrm{a}}$ & 6 & 26 & 6 & 6.4 & Zmijewski et al. (2006) \\
\hline Polish lake 2 & 7 & 28 & 9 & 2.6 & Jankowska et al. (2008) \\
\hline Lake X & 5 & 18 & 7 & 1.7 & Kucska et al. (2006) \\
\hline \multicolumn{6}{|l|}{ Roach } \\
\hline Baikal & 10 & 20 & 10 & 2.2 & Present paper \\
\hline Swedish lake $1^{\mathrm{a}}$ & 12 & 17 & 7 & 3.0 & Ahlgren et al. (1994) \\
\hline Swedish lake $2^{\mathrm{a}}$ & 7 & 25 & 10 & 2.2 & Ahlgren et al. (1994) \\
\hline Turkish lake & 9 & 6 & 3 & 1.9 & Uysal et al. (2008) \\
\hline \multicolumn{6}{|l|}{ Grayling } \\
\hline Baikal & 9 & 41 & 4 & 6.5 & Present paper \\
\hline Swedish river ${ }^{\mathrm{a}}$ & 9/8 (M/F) & 30/16 (M/F) & $5 / 4(\mathrm{M} / \mathrm{F})$ & 4.7/3.2 (M/F) & Ahlgren et al. (1994) \\
\hline Yenisei River $^{\mathrm{a}}$ & 11 & 29 & 2 & 9.6 & Sushchik et al. (2007) \\
\hline \multicolumn{6}{|l|}{ Ide } \\
\hline Baikal & 8 & 19 & 9 & 1.4 & Present paper \\
\hline Swedish lake $^{a}$ & 10 & 21 & 4 & 5.0 & Ahlgren et al. (1994) \\
\hline
\end{tabular}

in Fig. 3. This is another indication that tissue FA compositions are genetically controlled.

In line with this, Kozlova \& Khotimchenko (1993) determined the FA compositions of tissues of 2 other endemic Baikal fish species, Cottocomephorus grewingki and $C$. inermis. These 2 fish species from the same genus had very similar FA contents in their organs and tissues (liver, muscle and gonads) despite considerable differences in their diets. The authors concluded that the content of dominant FAs was probably determined by the systematic position of the species and their evolutionary history, rather than by ecology. This conclusion was strengthened in another investigation by the same authors, where they concluded that big golomyanka, which belongs to a different family than $C$. inermis, but is closely related to it in ecology and dietary selection, differed greatly in the contents of the dominant FAs (Kozlova \& Khotimchenko 2000).

The big and small golomyankas are by far the oldest endemic fish species in Lake Baikal, having become isolated from the North Pacific Ocean about 2 million yr ago (Kontula et al. 2003). They had a FA composition in their muscles which was more different from the other species than the differences within these species
(Fig. 2, Table S2), presumably in accordance with the reasoning put forward by Kozlova \& Khotimchenko (2000) that phylogeny is superior to ecology in determining tissue FA composition.

The dietary impact on the tissue FA composition in Lake Baikal fish was hypothesized to be low. Proving this would require investigations of the prey species. First, comprehensive mapping of all possible prey species would have to be carried out. Various fish species have common prey, but some prey species may also be unique to certain fish species. Because FA compositions will certainly vary considerably among prey species and between the prey and the predating fish, it would be very challenging to estimate the magnitude of the contribution of each prey species to the final FA composition in the tissue of a predator (Henderson \& Tocher 1987, Hessen \& Leu 2006). Therefore, it would be difficult to determine the importance of the diet on the tissue FA composition of the fish by just analysing the prey. The only way to solve this problem would be to conduct controlled feeding experiments. However, the calibration coefficients for the diet to tissue conversion of FAs obtained for one species may not be valid for another. Validating this would, therefore, be a formidable task, far beyond the scope of our investigation. 
The aspects discussed above advocate for a considerable metabolic, fundamentally genetic, influence on the tissue FA composition of Lake Baikal fish, in addition to a possible dietary influence. However, this does not fully explain the large intra-specific differences associated with different habitats (Table 4). Intra-specific differences in FA composition between age and size classes of fish may explain part of this variability (Ju et al. 1997). Still, it is quite obvious that the habitats are different in many ways, not only in their supply of dietary FAs. It has been suggested that environmental differences may lead to different patterns of gene expression (i.e. differences in the transcriptomes) among various populations (Liu 2007). In the same manner, pollution altered the gene expression of FA synthethase in a teleost fish, Fundulus heteroclitus, resulting in distinctions in tissue FA compositions (Oleksiak 2008, M. F. Oleksiak pers. comm.). Thus, it is possible that the reasons for the observed differences in tissue FA compositions between fish from the same species populating different lakes and rivers involve differences in gene expression in addition to differences in diet. Similar mechanisms have been hypothesized for different populations of fish in African lakes (Kwetegyeka et al. 2008).

We have shown that tissues of fish in Lake Baikal have species-specific FA compositions, with high proportions of n3 PUFAs, regarded as 'marine' FAs. However, levels of 'terrestrial' n6 PUFAs were also high, resulting in low n3/n6 PUFA ratios with freshwater characteristics. The differences in the FA profiles among the species followed the taxonomic differences, and it is hypothesized that these differences are not solely caused by differences in diet, but also by metabolic differences, and are likely founded on genetic differences. Thus, FA markers in tissues rich in structural phospholipids, such as fish heart and white muscle, should be tested further for use as markers of species, subspecies, populations or ecoforms. Since different classes of phospholipids have different fatty acyl structures, analysis of the actual molecular species profiles (combinations of 2 fatty acyl chains present in each class) by electrospray-ionization mass spectrometry would further elucidate the power and limits of different exogenous and endogenous factors in modifying the phospholipid FA compositions of fish. In contrast, the FA markers in tissues rich in storage lipids are more suitable as indicators of differences, or temporal changes, in trophic relationships. Even if temporal variation of temperature in the deep layers of Lake Baikal is very small, in the surface waters and shallow bays the seasonal changes in temperature $\left(>5^{\circ} \mathrm{C}\right)$ and ecosystem productivity are large. This calls for further investigations of intra- and inter-annual variability of the FA markers in Lake Baikal fish and their prey.
Acknowledgements. We thank A. I. Paulino and B. R. Olsen for their skillful technical assistance.

\section{LITERATURE CITED}

Ahlgren G, Blomqvist P, Boberg M, Gustafsson IB (1994) Fatty acid content of the dorsal muscle-an indicator of fat quality in freshwater fish. J Fish Biol 45:131-157

Bell MV, Henderson RJ, Sargent JR (1986) Minireview. The role of polyunsaturated fatty acids in fish. Comp Biochem Physiol 83:711-719

Blanchard G, Druart X, Kestemont P (2005) Lipid content and fatty acid composition of target tissues in wild Perca fluviatilis females in relation to hepatic status and gonad maturation. J Fish Biol 66:73-85

Bronte CR, Fleischer GW, Maistrenko SG, Pronin NM (1999) Stock structure of Lake Baikal omul as determined by whole-body morphology. J Fish Biol 54:787-798

Brooks S, Clark GT, Wright SM, Trueman RJ, Postle AD, Cossins AR, Maclean NM (2002) Electrospray ionisation mass spectrometric analysis of lipid restructuring in the carp (Cyprinus carpio L.) during cold acclimation. J Exp Biol 205:3989-3997

Burnham-Curtis MK, Ramme TM, Todd TN, Bronte CR, Fleischer GW, Pronin NM, Maistrenko SG (1999) Mitochondrial DNA variation among Lake Baikal, Coregonus autumnalis migratorius (Georgi). Adv Limnol 57:85-95

Chugunova NI (1959) Guidance for studying of fish age and growth. AS USSR, Moscow

Cooper MH, Budge SM, Springer AM, Sheffield G (2009) Resource partitioning by sympatric pagophilic seals in Alaska: monitoring effects of climate variation with fatty acids. Polar Biol 32:1137-1145

Dembitsky VM, Rezanka T, Kashin AG (1994) Comparative study of the endemic freshwater fauna of Lake Baikal. VI. Unusual fatty acid and lipid composition of the endemic sponge Lubomirskia baikalensis and its amphipod crustacean parasite Brandtia (Spinacanthus) parasitica. Comp Biochem Physiol B 109:415-426

Galasii GI (1993) Baikal. Atlas. Federal Service of Geodesy and Cartography of Russia, Moscow

Grahl-Nielsen O (2005) Fatty acid profiles as natural marks for stock identification. In: Cadrin SX, Friedland KD, Waldman JR (eds) Stock identification methods. Academic Press, New York, NY, p 239-261

> Grahl-Nielsen O, Glover KA (2010) Fatty acids in fish scales. Mar Biol 157:1567-1576

Grahl-Nielsen O, Mjaavatten O (1992) Discrimination of striped bass stocks: a new method based on chemometry of fatty acid profiles in heart tissue. Trans Am Fish Soc 121: 307-314

Grahl-Nielsen O, Ulvund KA (1990) Distinguishing populations of herring by chemometry of fatty acids. Am Fish Soc Symp 7:566-571

Hampton SE, Izmest'eva LR, Moore MV, Katz SL, Dennis B, Silow EA (2008) Sixty years of environmental change in the world's largest freshwater lake - Lake Baikal, Siberia. Glob Change Biol 14:1947-1958

Henderson RJ, Tocher DR (1987) The lipid composition and biochemistry of freshwater fish. Prog Lipid Res 26:281-347

Hessen DO, Leu E (2006) Trophic transfer and trophic modification of fatty acids in high Arctic lakes. Freshw Biol 51: 1987-1998

Hishikawa D, Shindou H, Kobayashi S, Nakanishi H, Taguchi R, Shimizu T (2008) Discovery of a lysophospholipid acyltransferase family essential for membrane asymmetry and 
diversity. Proc Natl Acad Sci USA 105:2830-2835

Jankowska B, Zakes Z, Zmijewski T, Szczepkowski M (2008) Fatty acid composition of wild and cultured northern pike (Esox lucius). J Appl Ichthyology 24:196-201

> Jankowska B, Zakes Z, Zmijewski T, Szczepkowski M (2010) Fatty acid profile of muscles, liver and mesenteric fat in wild and reared perch (Perca fluviatilis L.). Food Chem 118:764-768

> Joensen H, Grahl-Nielsen O (2004) Stock structure of Sebastes mentalla in the North Atlantic revealed by chemometry of the fatty acid profile in heart tissue. ICES J Mar Sci 61:113-126

> Joensen H, Steingrund P, Fjallstein I, Grahl-Nielsen O (2000) Discrimination between two reared stocks of cod (Gadus morhua) from the Faroe Islands by chemometry of the fatty acid composition in the heart tissue. Mar Biol 136:573-580

Ju SJ, Kucklick JR, Kozlova T, Harvey HR (1997) Lipid accumulation and fatty acid composition during maturation of three pelagic fish species in Lake Baikal. J Gt Lakes Res 23:241-253

Käkelä R, Mattila M, Hermansson M, Haimi P and others (2008) Seasonal acclimatization of brain lipidome in a eurythermal fish (Carassius carassius, L.) is mainly determined by temperature. Am J Physiol Regul Integr Comp Physiol 294:R1716-R1728

Kontula T, Kirilchik SV, Väinölä R (2003) Endemic diversification of the monophyletic cottoid fish species flock in Lake Baikal explored with mtDNA sequencing. Mol Phylogenet Evol 27:143-155

Kozlova TA, Khotimchenko SV (1993) Fatty acid composition of endemic Baikal fish and crustacea. Comp Biochem Physiol B 105:97-103

Kozlova TA, Khotimchenko SV (2000) Lipids and fatty acids of two pelagic cottoid fishes (Comephorus spp.) endemic to Lake Baikal. Comp Biochem Physiol B 126:477-485

Kucska B, Pal L, Müller T, Bodis M and others (2006) Changing of fat content and fatty acid profile of reared pike (ESox lucis) fed two different diets. Aquacult Res 37:96-101

Kvalheim OM, Karstang TV (1987) A general purpose program for multivariate data analysis. Chemom Intell Lab Syst 2:235-237

Kwetegyeka J, Mpango G, Grahl-Nielsen O (2008) Variation in fatty acid composition in muscle and heart tissues among species and populations of tropical fish in Lakes Victoria and Kyoga. Lipids 43:1017-1029

Liu ZJ (2007) Fish genomics and analytical genetic technologies, with examples of their potential applications in management of fish resources. In: Bartley DM, Harvey BJ, Pullin RSV (eds) FAO Fisheries Proceedings 5. Workshop on status and trends in aquatic genetic resources. FAO, Rome, p 145-179

Mackay AW, Ryves DB, Morely DW, Jewson DH, Rioual P (2006) Assessing the vulnerability of endemic diatom species in Lake Baikal to predicted future climate change: a multivariate approach. Glob Change Biol 12:2297-2315

Mairesse G, Thomas M, Gardeur JN, Brun-Bellut J (2006) Effects of geographic source, rearing system, and season on the nutritional quality of wild and farmed Perca fluviatilis. Lipids 41:221-229

Meier S, Mjøs SA, Joensen H, Grahl-Nielsen O (2006) Valida-

Editorial responsibility: Asbjørn Vøllestad, Oslo, Norway tion of a one-step extraction/methylation method for determination of fatty acids and cholesterol in marine tissues. J Chromatogr A 1104:291-298

> Moore MV, Hampton SE, Izmest'eva LR, Silow EA, Peshkova EV, Pavlov BK (2009) Climate change and the world's 'sacred sea' - Lake Baikal, Siberia. Bioscience 59:405-417

Morris RJ (1984) The endemic faunae of Lake Baikal: their general biochemistry and detailed lipid composition. Proc R Soc Lond B 222:51-78

Oleksiak MF (2008) Changes in gene expression due to chronic exposure to environmental pollutants. Aquat Toxicol 90:161-171

Olsen RE, Henderson RJ, McAndrew BJ (1990) The conversion of linoleic acid and linolenic acid to longer chain polyunsaturated fatty acids by tilapia (Oreochromis niloticus) in vivo. Fish Physiol Biochem 8:261-270

Orban E, Nevigato T, Masci M, Di Lena G and others (2007) Nutritional quality and safety of European perch (Perca fluviatilis) from three lakes of Central Italy. Food Chem 100:482-490

Sun MY, Clough LM, Carroll ML, Dai J, Ambrose WG, Lopez GR (2009) Different responses of two common Arctic macrobenthic species (Macoma balthica and Monoporeia affinis) to phytoplankton and ice algae: Will climate change impacts be species specific? J Exp Mar Biol Ecol 376:110-121

Sushchik NN, Gladyshev MI, Kalachova GS (2007) Seasonal dynamics of fatty acid content of a common food fish from the Yenisei River, Siberian grayling Thymallus arcticus. Food Chem 104:1353-1358

Timoshkin OA (2001) Index of animal species inhabiting Lake Baikal and its catchment area, Book 1. Novosibirsk Nauka, Novosibirsk (in Russian)

Uysal K, Bulbul M, Donmez M, Seckin AK (2008) Changes in some components of the muscle lipids of three freshwater fish species under natural extreme cold and temperate conditions. Fish Physiol Biochem 34:455-463

Velansky PV, Kostetsky E (2009) Thermoadaptation and fatty acid composition of main phospholipids of the smallscaled redfin Tribolodon brandti under natural and experimental conditions. Russ J Mar Biol 35:416-421

> Wold S (1978) Cross validation estimation of the number of components in factor and principal models. Technometrics 20:397-406

Wold S, Sjöström S (1977) SIMCA: a method for analyzing chemical data in terms of similarity and analogy. In: Kowalski BR (ed) Chemometrics: theory and applications, Vol 52. Symposium Series, American Chemical Society, Washington, DC, p 243-282

Xu X, Kestemont P (2002) Lipid metabolism and FA composition in tissues of Eurasian perch Perca fluviatilis as influenced by dietary fats. Lipids 37:297-304

> Xu X, Fontaine P, Melard C, Kestemont P (2002) Effects of dietary fat levels on growth, feed efficiency and biochemical compositions of Eurasian perch Perca fluviatilis. Aquacult Int 9:437-449

Zmijewski T, Kujawa R, Jankowska B, Kwiatkowska A, Mamcarz A (2006) Slaughter yield, proximate and fatty acid composition and sensory properties of rapfen (Aspius aspius L) with tissue of bream (Abramis brama L) and pike (Esox lucius L). J Food Composition Anal 19:176-181

Submitted: November 17, 2010; Accepted: May 12, 2011

Proofs received from author(s): June 22, 2011 